\title{
RHABDOTOPTERA STEIN, REDESCRIPTIONS OF THE GENUS AND OF $R$. STRIATIPENNIS STEIN (DIPTERA, MUSCIDAE)
}

\author{
Márcia Souto Couri ${ }^{1}$
}

\begin{abstract}
Redescriptions of Rhabdotoptera Stein and of R. striatipennis Stein, with discussion of the systematic position of the genus and description of the morphology of male terminalia, are given.

KEY WORDS. Diptera, Muscidae, Rhabdotoptera, Rhabdotoptera striatipennis, taxonomy
\end{abstract}

Rhabdotoptera was described by STEIN (1919), for Schoenomyza striatipennis Stein, 1911. After the original description, few references were made to this genus in literature (e.g. catalogues, keys).

The loan of the type of $R$. striatipennis by Dr. H. Schumann (Museum für Naturkunde der Humboldt - Universität, Berlin [ZMHU]) made it possible to redescribe the genus and the type species, and to describe the morphology of male terminalia.

\section{Rhabdotoptera Stein, 1919}

Rhabdotoptera Stein, 1919: 155 (description), - Sèguy, 1937: 223 (key), 237 (diagnosis), - Hennig, 1965: 67 (citation), - Pont, 1972: 38 (catalogue). - Couri \& Lopes. 1985: 593 (key). - Carvalho et al., 1993: 133 (catalogue).

Type species. Schoenomyza striatipennis Stein, 1919 (orig. desig.)

Diagnosis. Eyes with small and sparse cilia; male dichoptic; epistome not produced; antenna short, apex of flagellomere rounded; arista bare; palpi slender. Pre-alar absent; scutellum bare below and laterally; prosternum bare; proepisternals 2; propleurals 1, all upwards directed, acrostichals present before and after sutura, dorsocentrals 2:3, the anterior one about half of the length of the posterior one; katepisternals 1:1:1, forming an equilateral triangle and with an extra bristle beside anterior one (Fig. 1); lower calypter short, hardly projecting beyond the upper one; wings with bare veins; veins $R_{4+5}$ and $M_{1+2}$ parallel at apex. Legs with claws and pulvilli very small. Hind tibia at anterodorsal surface with one long median bristle, anteroventral surface with two short bristles at middle third, dorsal surface with a pre-apical bristle. Sternite I with few short cilia. Male: sternite V sub-triangular (Fig. 2); cercal plate sub-quadrate inferiorly (Figs. 3 and 4); hypandrium curved (Fig.5).

1) Departamento de Entomologia, Museu Nacional. Quinta da Boa Vista, São Cristóvão, 2094()-(04) Rio de Janeiro, Rio de Janeiro, Brasil. CNPy fellow. 
Comments. In COURI \& LOPES (1985) key, Rhabdotoptera appers wrongly as having dorsocentrals $1: 2$, instead of $2: 3$. Correcting this, it approaches couplet 25 of the key, differing from Oxytoneura Stein and Insulamyia Couri by having at the anterodorsal surface of hind tibia a long median bristle.

Although the katepisternum presents an extra bristle near the anterior one (Fig. 1, holotype; paratypes not examined), the other three bristles form an equilateral triangle, as the sinapomorphic condition for Coenosiini (sensu CARVAlHo 1989).

\section{Rhabdotoptera striatipennis Stein, 1911}

Figs 1-6

Schoenomyza striatipennis Stein, 1911: 85 (description).

Rhabdotoptera striatipennis; Stein, 1919: 156 (citation). - Sèguy, 1937: 238 (citation). - Pont, 1972: 38 (catalogue). - Carvalho et al., 1993: 133 (catalogue).

Holotype male labelled: Peru/21.I.04/Tarma [green label]; Type [red label]. Schoenomyza striatipennis/Stein/Type [handwriting]; Zool. Mus. Berlin. In good conditions, wings a little damaged at margin. Terminalia in a micro-vial with glycerin.

Coloration. Parafacial, parafrontal, face, lunule and genae brown, silvery pollinose. Ocellar triangle yellowish brown. Antenna brown; grey pollinose, arista reddish brown, palpus brown. Mesonotum greyish with two brown median stripes, which joint near scutellum and continue as a median stripe until apex of scutellum, and two lateral. Pleurae gray pollinose. Calypter whitish, halter brown. Wings colored as in figure 6. Legs brown, grey pollinose. Abdomen grey pollinose, with brown spots at disc of tergites III-V.

Male. Body length: $3.0 \mathrm{~mm}$; wing: $3.0 \mathrm{~mm}$.

Head. Eyes with very small and sparse cilia. Eyes separated, at anterior ocelli level, by a space about 0.43 of head width. Frons with four pairs of long bristles. Inner and outer vertical bristles longer, the last ones divergent. Antenna with flagellomere measuring about 1.5 length of pedicel.

Thorax. Acrostichal pre-sutural three, post-sutural four pairs; humerus with two bristles. Notopleuron with two similar and long bristles. Scutellum with a lateral median and an apical pair of strong bristles. Fore femur at posterodorsal and posteroventral surfaces with a row of bristles. Fore tibia at dorsal surface with a preapical bristle. Mid femur at anterodorsal surface with a row of bristles at basal half. Mid tibia at anterodorsal surface with one long sub-median bristle; posterior surface with a median bristle, shorter than the former; dorsal surface with a pre-apical bristle; anteroventral, anterodorsal and ventral surfaces with an apical bristle, the two first ones longer. Hind femur at anterodorsal surface with a row of bristles; anteroventral surface with bristles at apical third; dorsal surface with a pre-apical bristle. Hind tibia at anterodorsal surface with a median bristle; anteroventral surface with two short bristles at middle third; dorsal surface with a pre-apical long bristle.

Abdomen. Tergites without long bristles. Sternite V with bristles more numerous laterally (Fig. 2). 
Terminalia. Cercal plate with sharp inferior margin (Fig. 3, 4); aedeagal apodeme surpassing margin of hypandrium, basiphalus and distiphalus similar in size (Fig. 5).

Comments. This is the only known species described in this genus. Although only the male is herein described, $R$. striatipennis is also known from female ( 3 males and 7 females in the original series).

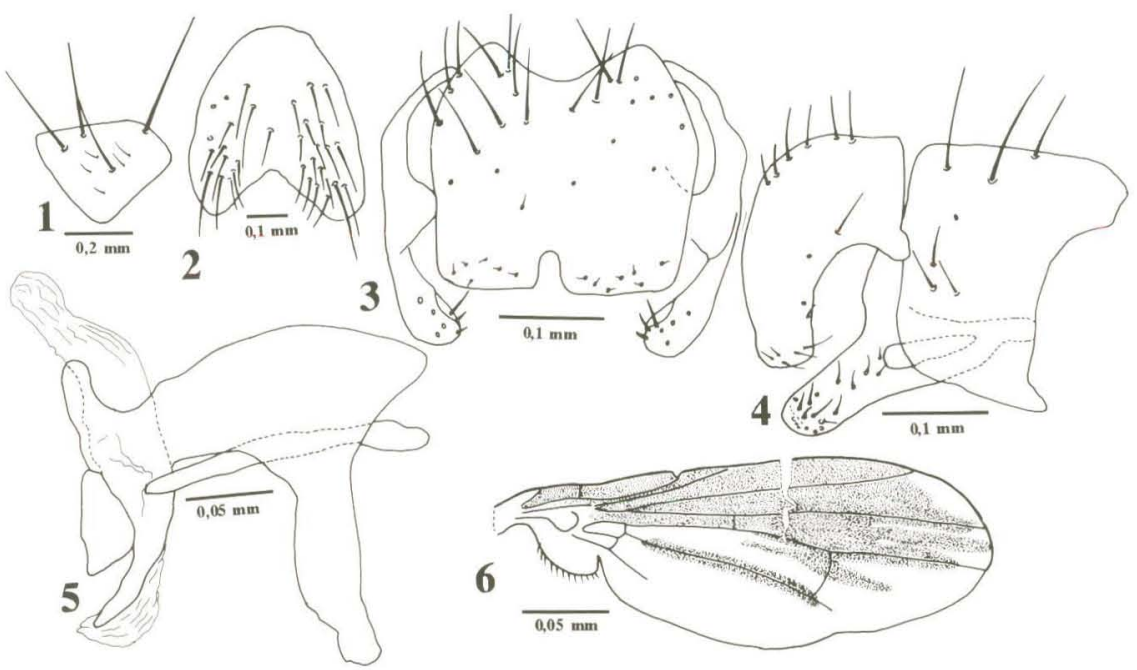

Figs 1-6. Rhabdotoptera striatipennis, holotype male. (1) Sternopleuron; (2) sternite V, dorsal view; (3) cercal plate and surstyli, dorsal view; (4) cercal plate and surstyli, lateral view; (5) phallic complex, lateral view; (6) wing.

ACKNOWLEDGMENTS. I am grateful to Dr. H. Schumann (Museum für Naturkunde der Humboldt Universität, Berlin) for the loan of this type.

\section{REFERENCES}

Carvalho, C.J.B. 1989. Classificação de Muscidae (Diptera): uma proposta através da análise cladística. Revta bras. Zool.6 (4): 627-648.

Carvalho, C.J.B.; M.S. Couri; A.C. Pont; D. Pamplona \& S.M. Lopes. 1993. Part II. Muscidae, p.201. In: C.J.B. Carvalho (Ed.). A Catalogue of the Fanniidae and Muscidae (Diptera) of the Neotropical Region. São Paulo, Sociedade Brasileira de Entomologia, 201p.

COURI, M.S. \& S.M. LOPES. 1985. Neotropical genera of Coenosiinae nomenclatural notes and key to identification (Diptera, Muscidae). Rev. Brasil. Biol. 45 (4): 589-595.

HeNNIG, W. 1965. Vorarbeiten zu einem phylogenetischen System der Muscidae (Diptera: Cyclorrapha). Beiträge Naturkunde, Stuttgart, 141: 100p. 
PONT, A.C. 1972. A Catalogue of the Diptera of the Americas South of the United States. São Paulo, Museu de Zoologia, Universidade de São Paulo, vol. $97,111 \mathrm{p}$.

SÉGuY, E. 1937. Diptera, Family Muscidae. In: P. Wystman (Ed.). Genera Insect. (205): 604p.

Stein, P. 1911. Die von Schnuse in Südamerika gefangenem Anthomyiden. Arch. Naturgesch. 77 (1): 61-189. . 1919. Die Anthomyidengattungen der Welt, analytisch bearbeitet, nebst einem kritisch-systematischen Verzeichnis aller aussereuropäischen Arten. Arch. Naturgesch. 83 A 1: 85-178 [1917]. 